\title{
ANÁLISE FENOMENOLÓGICA DA PERCEPÇÃO DOS PACIENTES EM CUIDADOS PALIATIVOS
}

\author{
Phenomenological analysis of patients perception in palliative care
}

\author{
Maria Inês Amaro Assunção de Melo ${ }^{1}$ \\ Waldir Souza ${ }^{2}$
}

\section{RESUMO}

O artigo analisa a percepção dos pacientes em cuidados paliativos e aplica o método fenomenológico steiniano. Trata-se de pesquisa fenomenológica, transversal, descritiva e qualitativa, de amostragem assimétrica, aleatória com participação de 8 pacientes em cuidados paliativos, de faixa etária igual ou maior que 18 anos, realizada no hospital. Consta de um roteiro de entrevistas semiestruturado, aplicado aos pacientes em cuidados paliativos nos seguintes setores: ambulatório e internamento. As entrevistas foram gravadas em áudio e posteriormente transcritas. O método adotado é o fenomenológico de Edith Stein, baseado em três obras: “La struttura della persona umana (1933-2013); L' Empatia di Edith Stein (19171992); Psicologia e Scienze dello Spirito (1922-1999)”. Os resultados da pesquisa apontam a percepção dos pacientes em cuidados paliativos, utiliza a ferramenta Atlas.ti.8 para auxiliar, operacionalizar e organizar os dados, elege a codificação percepção, a partir da individualidade de cada paciente e atinge as codificações gerais, por semelhanças. A análise da percepção indicam que os pacientes são os meios para estabelecer as relações intersubjetivas, intrassubjetivas e facilitadores para a equipe de saúde, a família e os demais envolvidos nos cuidados paliativos.

Palavras-chave: Fenomenologia. Pacientes. Cuidados Paliativos

\begin{abstract}
The article analyzes the perception of patients in palliative care and applies the Steinian phenomenological method. This is a phenomenological, cross-sectional, descriptive and qualitative research, with an asymmetric, random sample with the participation of 8 patients in palliative care, aged 18 years or older, carried out in the hospital. It consists of a semi-structured interview script, applied to patients in palliative care in the following sectors: outpatient and inpatient. The interviews were recorded on audio and later transcribed. The method adopted is the phenomenological one by Edith Stein, based on three works: "La struttura della persona umana (1933-2013); L 'Empatia di Edith Stein (1917-1992); Psychology and Scienze dello Spirito (1922-1999)". The results of the research point to the perception of patients in palliative care, use the tool Atlas.ti.8 to assist, operationalize and organize the data, choose the perception coding, based on the individuality of each patient and reach the general codifications, by similarities. The perception analysis indicates that patients are the means to establish intersubjective, intrasubjective and facilitating relationships for the health team, the family and others involved in palliative care.
\end{abstract}

\footnotetext{
${ }^{1}$ Doutora em Teologia pela Pontifícia Universidade Católica do Paraná (PUCPR). Mestre em Bioética pela Pontifícia Universidade Católica do Paraná (PUCPR). Pós- Graduação em Psicologia da Saúde - Faculdade Pequeno Príncipe. Pós-Graduação em Psicologia Hospitalar- Faculdades Pequeno Príncipe, Curitiba-PR. Psicóloga Hospitalar/Saúde/Clínica.

${ }^{2}$ Doutor em Teologia, Professor Adjunto da Pontifícia Universidade Católica do Paraná (PUCPR) nos Programas de Pós-Graduação em Teologia (Doutorado e Mestrado) e Bioética (Mestrado), Curitiba-PR.
} 
Keywords: Phenomenology. Patients. Palliative care

\section{Introdução}

A fenomenologia steiniana prioriza as qualidades básicas e necessárias da estrutura da pessoa humana, que auxilia na compreensão singular de cada indivíduo (STEIN, 1933-2013). A partir do método fenomenológico steiniano é possível compreender a percepção dos pacientes em cuidados paliativos, considerando a percepção externa e interna. A percepção externa corresponde ao ato no qual o ser humano experimenta o mundo exterior, ou seja, os fenômenos que estão ligados aos cuidados paliativos. Eles são caracterizados pelas próprias percepções e de outros pacientes que estão sob os cuidados paliativos. Assim sendo, ao contrário da percepção externa, a interna corresponde à interioridade da pessoa humana. A partir da análise da percepção dos pacientes é possível correlacionar a importância dos cuidados paliativos. Os cuidados paliativos promovem a qualidade de vida dos pacientes e dos familiares, buscam a prevenção e o alívio do sofrimento, a identificação precoce do tratamento, a avaliação cuidadosa da dor e outros sintomas físicos, sociais, psicológicos e espirituais. Desta maneira, os cuidados à pessoa humana são ampliados na medida em que a doença avança. O tratamento de cuidados paliativos é prioritário para garantir conforto, dignidade aos pacientes e familiares, enquanto processo contínuo e dinâmico (INCA, 2020).

\section{Procedimentos metodológicos}

A pesquisa é fenomenológica de campo, transversal, descritiva e qualitativa. A revisão é sistemática de literatura, apresentando uma investigação focada e bem definida, visando identificar, selecionar, avaliar e sintetizar as evidências relevantes disponíveis e abrangentes (GALVÃO, 2014, p.183; MINAYO, 2004, p. 220-223). O software ATLAS.ti. 8, foi utilizado para auxiliar no emprego do método fenomenológico, sua operacionalização, sistematização e a organização dos dados coletados (SALDAÑA, 2013, pp. 3, 41) 3 . O método fenomenológico de Edith Stein, está baseado em três obras: “La struttura della persona umana (1933-2013); L” Empatia di Edith Stein (1917-1992); Psicologia e Scienze dello Spirito (1922-1999)”, articula toda a fundamentação teórica, resultados e análise.

${ }^{3}$ Código “code”, na pesquisa qualitativa é uma palavra ou frase curta que atribui simbolicamente um atributo notável para captar a essência. As citações “quotations”, se referem aos comentários do observador, às impressões subjetivas ou às notas analíticas. Memórias de análise “memos”, são as memórias de análise dos fenômenos, onde estão contidos os dados do processo de investigação dos participantes de pesquisa, examinados e refletidos. 
A coleta dos dados foi realizada em uma instituição hospitalar de São Paulo-SP, ocorrendo de forma sistemática, tendo como prerrogativa, pacientes em cuidados paliativos. A amostra assimétrica, aleatória, não sistematizada, com 8 participantes em cuidados paliativos de faixa etária igual ou maior que 18 anos. O roteiro de entrevistas semiestruturado, foi aplicado aos pacientes em cuidados paliativos nos setores: ambulatório e internamento. As entrevistas foram gravadas em áudio e posteriormente transcritas na íntegra. Os dados qualitativos da pesquisa, expressam a complexidade dos fenômenos que designam um amplo recurso utilizado para definir procedimentos e as qualidades percebíveis da investigação (BICUDO, 2011; MARCONI; LAKATOS, 2011; ANDRADE; HOLANDA, 2000).

Os critérios de inclusão da pesquisa são pacientes em cuidados paliativos a nível ambulatorial e internamento, com faixa etária igual ou maior de 18 anos. Foram excluídos pacientes entubados, sedados, com rebaixamento de nível de consciência, justificados pela escala Glasgow, distúrbios neurológicos, incapazes de arguição e, ou aqueles que não desejavam participar. A pesquisa cumpriu a Resolução CNS/MS 466/12 (BRASIL, 2012), obtendo a aprovação em dois CEPs ${ }^{4}$.

\section{Resultados}

Os resultados da pesquisa fenomenológica advém dos dados retirados das arguições dos pacientes e organizados no software Atlas.ti8. Após a estruturação dos dados, foram atribuídas as codificações denominadas percepção. O roteiro de entrevista semiestruturado é composto de 6 questões disparadoras e as siglas correspondem às iniciais das perguntas, vide abaixo a tabela1.

Tabela 1 - Roteiro de entrevistas

\begin{tabular}{|c|c|}
\hline Perguntas disparadoras & Siglas \\
\hline 01. O que você pode descrever nesta fase da vida sobre a sua pessoa? & 1.DFVP \\
\hline 02. O que é para você participar dos cuidados paliativos? & 2. VPCP \\
\hline $\begin{array}{l}\text { 03. Neste período da vida no qual emergem emoções e sentimentos, gostaria de } \\
\text { compreender o seu pensamento em relação aos cuidados paliativos? }\end{array}$ & 3.CRCP \\
\hline 04. Quais são suas preocupações atuais nos cuidados paliativos? & 4.SPCP \\
\hline 05. O que você pensa sobre a vida? & 5.VPSV \\
\hline 06. Onde você está neste caminho que ainda deve percorrer ao longo da vida? & 6.CPLV \\
\hline
\end{tabular}

Fonte: a autora, 2020.

${ }^{4}$ De acordo com a Resolução n466/12 e a Resolução n ${ }^{\circ}$ 510/16, toda pesquisa envolvendo seres humanos deve ser submetida à apreciação de um Comitê de ética em pesquisa (CEP). 
A tabela 2 ilustra a caracterização da população dos 8 pacientes, enumerados aleatoriamente. Os códigos indicam o diagnóstico, a localização dos pacientes a nível ambulatorial e internamento, a religião, o tempo de tratamento nos cuidados paliativos, a idade e o sexo.

Tabela 2 - Caracterização da população

\begin{tabular}{|c|c|c|c|c|c|c|}
\hline Paciente & $\mathrm{CD}$ & CHII ou CHA & $\mathrm{CR}$ & $\mathrm{CT}$ & $\mathrm{CI}$ & CS \\
\hline 01 & Câncer De Pulmão & Ambulatorial & Católica & 5 meses & 62 anos & Masculino \\
\hline 02 & $\begin{array}{l}\text { Câncer de mama, } \\
\text { metástase óssea }\end{array}$ & Ambulatorial & Evangélica & 5 anos & 51 anos & Feminino \\
\hline 03 & Câncer de fígado & Ambulatorial & Evangélica & $\begin{array}{l}1 \text { mês e } \\
15 \text { dias }\end{array}$ & 64 anos & Masculino \\
\hline 04 & $\begin{array}{l}\text { Câncer de pulmão e } \\
\text { HIV }\end{array}$ & Ambulatorial & Evangélica & 8 anos & 48 anos & Masculino \\
\hline 05 & $\begin{array}{l}\text { Carcinoma de } \\
\text { faringe }\end{array}$ & Ambulatorial & Evangélica & 2 meses & 64 anos & Masculino \\
\hline 06 & $\begin{array}{l}\text { Osteossarcoma de } \\
\text { quadril }\end{array}$ & Internamento & Católica & 15 dias & 43 anos & Feminino \\
\hline 07 & $\begin{array}{l}\text { Adenocarcinoma } \\
\text { gástrico }\end{array}$ & Internamento & Evangélico & 2 meses & 56 anos & Masculino \\
\hline 08 & Câncer de reto & Internamento & Católico & 1,5 horas & 57 anos & Masculino \\
\hline
\end{tabular}

Fonte: a autora, 2020.

Os resultados levantados no primeiro momento partem da captura das percepções individuais de cada paciente, através das arguições das experiências de vida, de doença e de tratamento. As arguições dos pacientes em cuidados paliativos, somam o total de 51 códigos percepção. Os códigos não são estáticos e não seguem nenhuma sequência lógica, mas pressupõem previamente o raciocínio daquilo que é percebido pelos pacientes.

As percepções individuais de cada paciente priorizaram a não repetição das palavras, vícios de linguagem, expõe fragmentos e palavras, que melhor representam a relação entre código e arguições dos pacientes. Os aspectos envolvidos evidenciam a condição atual do paciente, a história de vida, a descrição da doença, o passado, o presente e o futuro das histórias de vida deles se misturam sem distinção.

A veemência resultante do paciente (01) em relação a ocorrência do código percepção, indica aquilo que é percebido pessoalmente por ele, em 1 . DFVP, aponta o "aumento 5 dos pensamentos, dúvida em relação aos exames”. Ainda “a dúvida em relação ao que está acontecendo...em decorrência da grave doença”. Em relação a 2. VPCP, está em evidência “a preocupação em comparação aquilo que era antes...o presente...considera muitas coisas.”

${ }^{5}$ A transcrição é literal. 
Essa “preocupação diminui após o cuidado médico em específico a doutora”. Desta maneira, "percebe nessa doutora em específico o resultado de um tratamento paliativo pelo acolhimento, sentimento de "importância com a sua vida e as perguntas sobre ela, a tranquilidade e a vontade reaparecem...junto dela.” Já em 3. CRCP, aponta o “período de descreditação, que se torna em sentimento de acreditação, através dos cuidados paliativos e por meio da doutora." Para 4. SPCP, "não há indicação de preocupação com os cuidados paliativos, mas existe em relação ao próprio diagnóstico.” A 5. VPSV apura o “atraso de vida em decorrência dos vícios.” Bem como a percepção da "epilepsia aumenta a necessidade de parar consumo de álcool” Ainda aponta a "descoberta do câncer...a interrupção do uso de fumo e álcool”. Na 6. CPLV não foram encontrados registros de codificações de percepção.

Para o paciente (02) os resultados apontam na codificação percepção 1. DFVP, o registro de "crescimento pessoal, em relação à vida antes da doença...as relações familiares eram deixadas de lado". Na 2. VPCP, a percepção sugere no início do tratamento o "não entendimento acerca dos cuidados paliativos" e “quando começa a fazer parte passa a gostar... levanta a autoestima, o ânimo, através das conversas, vê o amor e a dedicação dos médicos”, expõe também que "é comum que a pessoa esteja em último estágio, mas os $C P^{6}$ permite a morte tranquila e sem dor." Assim, "o médico paliativo é aquele que me cuida, ensina, isso está registrado na memória...vi e senti.” A descrição demonstra “...choro e emoção...contentamento” pela boa condição de vida física e psíquica “o significado primeiro dos cuidados paliativos é internalizado como fim de vida... e na verdade é vida...” Em menção ao "diagnóstico...quem faz é a própria pessoa, se o diagnóstico é ruim, a pessoa deixa de se cuidar e deixa a doença levar." Indica o tratamento, seja, ele "cirurgia, quimioterapia, se for para viver, viverei, se for para morrer... o tempo...acabou.” No tocante da 3. CRCP, resulta do período de vida em que "recebe o diagnóstico do dia para a noite. Percebe a doença e a vida ...o afastamento das irmãs...os problemas familiares. Entende a vida como algo de alegria, família...” Em relação a “coisa material que adquire lugar de importância, passa a sentir o abandono e o sentimento de ser ignorada...desalento". Na 4. SPCP, desvela "a mudança dos cuidados paliativos...hoje... gosto de vir, porque vivo alegre. Não entro em todos os médicos...como entro aqui...” Também aponta “duas escolhas de pensamento, o que significa paliativo? vida ou morte... qual o tratamento?... cada vez mais dor, os médicos vão amenizar a dor... para... um estágio de morte mais tranquila.... o remédio...é para tirar a dor e ...melhorar a qualidade de vida...Escolha de vida e não de morte.” Na 5. VPSV, expõe “...viver a vida

${ }^{6} \mathrm{CP}=$ Cuidados Paliativos 
para si próprio... filhos, esposo... neto... alegrando, porque estou de pé... A vida é... boas, amizades...ajudar os que precisam... levar o conhecimento...” Na sequência em "fases de vida... amar primeiro...amar o outro...” Em 6. CPLV, mostra a “... fase de vida...momento de não precisar tanto do hospital...pensamento bom em relação vida atual...” Outrossim, revela “não...muito forte o tempo todo... às vezes dor de cabeça...mas ... não passo tristeza... pela doença...”.

O indicativo da resultante para o paciente (03) na ocorrência da codificação percepção 1. DFVP, demonstra o corpo modificado pela doença “um amarelo que apareceu na perna...há um ano e quatro meses...” Na 2. VPCP, percebe os cuidados paliativos como “... normal... as conversas... encara o quadro com naturalidade.” Bem como, revela o “... vazamento nas vias biliares...é um tumor ou não é...se é um tumor vai...aparecer...” Na 5. VPSV, vislumbra o sentimento de “...inútil... A vida tem que ter uma utilidade...” A 6. CPLV, indica a temporalidade da doença "um ano e quatro meses..."

Em relação ao paciente (04) para a codificação percepção 1. DFVP, expressa “...não prazer pela vida... essa... realidade.” Não há evidências comprovadas para as codificações percepção em 2. VPCP. Já em 3. CRCP, expõe “...a força...que advém da esposa e filhas... É... a razão do viver...” Em 4. SPCP, a evidência de “.... preocupação em deixar a família desamparada... sem aposentaria... sem condições financeiras...depois que conquistar isso, posso ir...”. A 5. VPSV, indica o pensamento em relação “...a vida...a vontade de para-la...” Bem como, na 6. CPLV, também não há indícios para a codificação percepção.

A resultante do paciente (05) em codificação percepção 1. DFVP, situa “...os amigos... o sentir contente... nunca triste... o coração alegre... não tenho o que reclamar...” Assim como, revela “...a esposa como tudo, ela ajuda... vivo melhor... a vida...”. Na sequência não há ocorrência para a codificação percepção em 2. VPCP. Em 3. CRCP, a percepção expõe que “...tem que ter muita humildade, ... potencial... amar o outro com... sinceridade, compreender os erros, pedir perdão...procurar não...magoar as pessoas...” Em 4. SPCP, abrange a “... mulher que...está sempre preocupada... os netos... e os filhos...”. A 5. VPSV, a percepção resulta “... a harmonia de viver...bem...juntos...não podemos ficar ofendendo as pessoas, isso magoa... demais. A vida é boa...se a gente deve respeitar a vida...” Na 6. CPLV, indica o “...pedido de desculpa... gritei com minha neta sem esperar que ela fosse falar...você me perdoa...ela perdoou... isso vai aumentando um pouquinho a vida da gente...” Da mesma forma reporta ao “... homem que tinha muita saúde, fazia de tudo, cuidava bem das pessoas, isso leva ao aborrecimento, mas vou fazer o que é consequência da vida...”. 
Para o paciente (06) não há evidências de ocorrência para a codificação percepção 1. DFVP e 2. VPCP. A 3. CRCP, expressa a “...não sabe explicar o momento... não consigo....” Em 4. SPCP não há ocorrências de codificações percepção. Na 5. VPSV não há evidências para as codificações percepção. Para 6. CPLV, indica “... o desejo de estar com eles, com os filhos, na minha casa com minha filha me cuidando.”.

O paciente (07) em 1. DFVP, a codificação percepção expõe “... o sentir -se bem graças a Deus... e à família... levo a vida para frente.”. Para 2. VPCP, alude “...tive que operar...uma operação de risco...estou com muito sangramento.” Em 3. CRCP, resulta “... no ficar pensando longe...penso coisas positivas, não negativas...” A 4. SPCP, expõe “... indo bem graças a Deus... me tratam bem com a comida e com cuidados médicos...” Na 5. VPSV não foram encontradas comprovações para as codificações percepção. Em 6. CPLV, mostra “...a família mais unida... Minha mãe...com oitenta e ... seis anos veio... me ver...” Bem como, apresenta a resultante “... aos... poucos, fui parando...com o cigarro...não coloquei mais na boca não, fumei... 48 anos."

O paciente (08) não há evidências em 1. DFVP que assinalem ocorrência para a codificação percepção. Para 2. VPCP, codificação percepção encontra “... agradecer...a quem está aqui me cuidando fora Jesus e vocês...ajudando nesse momento.” Em 3. CRCP, esclarece “...as emoções não chegam muito...mas...está bom... porque... tenho um tratamento, mais preciso mais presente...com alívio na dor ...e tem alguém cuidando de mim...”. A 4. SPCP, comprova “... a preocupação na minha vida... chefe de família... tem muita coisa boa... muitos planos... fico até...com a cabeça ...confusa, porque tem muitos planos...que não consigo realizar...”. Para 5. VPSV não foram encontradas comprovações para ocorrências de codificações percepção. Para 6. CPLV, a percepção exibe “...perdi minha mulher... dia 28 de dezembro aqui mesmo no Hospital...câncer de mama...começo a lembrar... o sonho dela...”. Vide, quadro 1, percepção dos fatores evidenciados na individualidade de cada paciente.

Quadro 1- Percepção- fatores evidenciados

\begin{tabular}{|l|l|}
\hline Pacientes & Percepção- fatores evidenciados \\
\hline 01 & $\begin{array}{l}\text { Dúvidas em relação a doença; A doença; o diagnóstico; os vícios e a vida anterior; O cuidado } \\
\text { médico; Acolhimento; Importância a vida; Tranquilidade; Vontade; Acreditar }\end{array}$ \\
\hline 02 & $\begin{array}{l}\text { Crescimento pessoal; CP levanta a autoestima; diálogos médicos; amor e dedicação; CP permite a } \\
\text { morte tranquila e sem dor; CP cuida e ensina; CP choro e emoção; O diagnóstico quem faz é própria } \\
\text { pessoa; Disposição para o tratamento; O impacto do diagnóstico; Tratamento psicólogo destinado } \\
\text { a questões familiares e não a doença; Vida como algo de alegria; família; Abandono e ignoração; } \\
\text { Incerteza da vida; Viver para si e para a família; procurar pessoas boas; amizades sinceras; Não } \\
\text { tristeza pela doença }\end{array}$ \\
\hline 03 & $\begin{array}{l}\text { Tratamento; CP normal; natural; O corpo adoecido; Sentimento de inutilidade; Tempo de } \\
\text { investigação da doença }\end{array}$ \\
\hline 04 & $\begin{array}{l}\text { Não há prazer de viver; Razão do viver é a família; Preocupação financeira com a família em } \\
\text { relação a própria morte; Parar a vida }\end{array}$ \\
\hline
\end{tabular}




\begin{tabular}{|l|l|}
\hline 05 & $\begin{array}{l}\text { Sentimento de contentamento; não tristeza; O cuidado que a esposa realiza; Características } \\
\text { necessárias humildade; potencial; amor; sinceridade e compreensão dos erros; Harmonia na vida; } \\
\text { Capacidade de perdão; Referência temporal ao passado de saúde e a doença no presente }\end{array}$ \\
\hline 06 & $\begin{array}{l}\text { Não consegue explicar os sentimentos e as emoções contidos; Desejo de estar com os filhos e em } \\
\text { casa }\end{array}$ \\
\hline 07 & $\begin{array}{l}\text { Sente-se bem graças a Deus; a família e aos médicos; leva a vida a frente; Pensamento positivo; } \\
\text { Dependência ao fumo }\end{array}$ \\
\hline 08 & $\begin{array}{l}\text { Agradece aos cuidados de todos e de Jesus; Tratamento preciso; alívio da dor e do sofrimento; } \\
\text { Preocupação com a família e os planos não realizados; Lembrança da perda da mulher por câncer; } \\
\text { o sonho não concretizado }\end{array}$ \\
\hline
\end{tabular}

Fonte: a autora, 2020.

As codificações gerais percepção partem das características individuais, agrupadas por semelhanças em evidências comprovadas nas arguições dos pacientes. A vida, as emoções, os tratamentos em relação aos cuidados paliativos, advém de três especificidades encontradas: em relação ao tratamento; em relação a doença; em relação aos sentimentos positivos e negativos. Para a codificação percepção em relação ao tratamento, comprovam o cuidado médico, o cuidado familiar, a disposição, o acolhimento e a acreditação. No que tange a especificidade dos cuidados paliativos, apontam como natural, normal, preciso, que alivia a dor e o sofrimento. Eles também são aqueles que ensinam e cuidam na integralidade e que permitem a morte tranquila e indolor.

Em relação a doença percebem o diagnóstico, o impacto, a vida anterior, às dúvidas a respeito da doença, comum à essa fase inicial e a referência temporal em relação ao passado de saúde e a doença no presente. Bem como, o corpo adoecido, o tempo de investigação da doença, a preocupação financeira com a família em relação à morte, ou seja, sobretudo se o provedor financeiro da família não conseguiu concretizar os planos, para deixar a família com uma certa estabilidade financeira. Outrossim, em relação à doença são as características necessárias para enfrentar, como: humildade, potencial, amor, sinceridade, compreensão dos erros, vontade e tranquilidade.

Para os sentimentos envolvidos é possível perceber nos sentimentos positivos o contentamento pelo momento de vida, a não tristeza pela condição de doença, o crescimento pessoal, a importância, a alegria, a harmonia na vida e capacidade de perdão. E, ainda em relação aos aspectos positivos que os cuidados paliativos representam para os pacientes, através das conversas médicas que aconchegam, levantam a autoestima, o amor e a dedicação. Assim, como o desejo de estar junto da família.

De outro, os sentimentos negativos revelam inutilidade, o não prazer pela vida, a vontade de parar a vida, a perda de outros da família pela doença e a frustração pelos sonhos e planos não concretizados ao longo da vida, também, a própria incerteza da vida, o abandono e 
a indignação. A tabela 3, engloba as semelhanças das três especificações encontradas para a percepção.

Tabela 3 - Codificação geral da percepção em relação às especificidades

\begin{tabular}{|c|c|c|c|}
\hline \multicolumn{4}{|l|}{ Percepção } \\
\hline \multirow{2}{*}{$\begin{array}{l}\text { Em relação } \\
\text { tratamento }\end{array}$} & \multirow{2}{*}{ Em relação a doença } & \multicolumn{2}{|c|}{ Em Relação aos sentimentos } \\
\hline & & Positivos & Negativos \\
\hline O cuidado médico & $\begin{array}{l}\text { Dúvidas em relação a } \\
\text { doença }\end{array}$ & Crescimento pessoal & Abandono e ignoração \\
\hline Acolhimento & $\begin{array}{l}\text { A doença, diagnóstico, } \\
\text { vícios e a vida anterior }\end{array}$ & $\begin{array}{l}\text { CP levanta a autoestima, } \\
\text { conversas médicas, amor, } \\
\text { dedicação }\end{array}$ & Incerteza da vida \\
\hline Importância a vida & Tranquilidade & $\begin{array}{l}\text { Vida como algo de } \\
\text { alegria, família }\end{array}$ & $\begin{array}{l}\text { Sentimento } \\
\text { inutilidade }\end{array}$ \\
\hline Acreditar & O impacto do diagnóstico & $\begin{array}{l}\text { Não tristeza pela } \\
\text { condição de doença }\end{array}$ & Não há prazer de viver \\
\hline $\begin{array}{l}\mathrm{CP} \text { permite a morte } \\
\text { tranquila e sem dor }\end{array}$ & O corpo adoecido & $\begin{array}{l}\text { Sentimento de } \\
\text { contentamento }\end{array}$ & os planos não realizados \\
\hline CP cuida e ensina & $\begin{array}{l}\text { Tempo de investigação da } \\
\text { doença }\end{array}$ & Harmonia na vida & $\begin{array}{l}\text { Lembrança das perdas, } \\
\text { os sonhos e planos não } \\
\text { concretizados }\end{array}$ \\
\hline $\begin{array}{l}\text { Disposição para } \quad \text { o } \\
\text { tratamento }\end{array}$ & $\begin{array}{l}\text { Preocupação financeira } \\
\text { com a família em relação a } \\
\text { própria morte }\end{array}$ & Capacidade de perdão & \\
\hline $\begin{array}{l}\text { Sente-se bem graças a } \\
\text { Deus, a família e aos } \\
\text { médicos }\end{array}$ & $\begin{array}{l}\text { Características necessárias } \\
\text { humildade, potencial, } \\
\text { amor, sinceridade e } \\
\text { compreensão dos erros }\end{array}$ & $\begin{array}{l}\text { Desejo de estar com a } \\
\text { família e em casa }\end{array}$ & \\
\hline $\begin{array}{l}\text { Tratamento preciso, } \\
\text { alívio da dor e do } \\
\text { sofrimento } \\
\text { CP normal, natural } \\
\text { O cuidado que a família } \\
\text { realiza } \\
\text { Tratamento }\end{array}$ & $\begin{array}{l}\text { Referência temporal ao } \\
\text { passado de saúde e a } \\
\text { doença no presente } \\
\text { Preocupação com a família } \\
\text { Descoberta da doença e } \\
\text { perda da saúde }\end{array}$ & Pensamento positivo & \\
\hline
\end{tabular}

Fonte: a autora, 2020.

\section{Análises dos resultados}

Essa etapa configura a unificação dos resultados em relação às obras de Edith Stein, que serão ilustradas pelas memórias de análise (SALDAÑA, 2013, p. 41). As memórias de análise foram denominadas de acordo com as arguições dos pacientes e em relação à teoria de Edith Stein. Foram encontradas e examinadas 53 memórias de análise na codificação percepção. Os fenômenos contidos nos dados das arguições possibilitam conexões, a partir do exame das percepções dos pacientes em cuidados paliativos. As codificações gerais percepção, estão especificadas em três realidades: em relação ao tratamento; em relação à doença; em relação aos sentimentos, positivos e negativos.

\section{Codificações gerais percepção: em relação ao tratamento}


Em relação ao tratamento na memória de análise denominada abertura interna e externa $^{7}$, as palavras sinalizam a abertura de uma relação entre médico e paciente, onde é possível certificar nas arguições "tranquilidade e intimidade”. Existe uma certa proximidade, que se assemelha ao lugar de um “filho” que "propicia acolhimento” e escuta das experiências vividas. É possível compreender que o ser humano experimenta a existência humana e a humanidade nos outros e em si mesmo. A percepção exterior do próprio corpo não é a ponte para a experiência do próprio eu. O corpo percebido exteriormente, não pode ser considerado como experiência fundamental, ele se funde com a percepção do interior na qual, o eu sente o corpo vivente em si mesmo. Isso implica um eu consciente de si mesmo e não somente do corpo vivente, mas de todo o eu corporal-animado-espiritual. Portanto, o ser humano tem uma abertura externa e interna, ou seja, uma aberta internamente para si próprio e outra externa, onde ele colhe em si o mundo. O corpo físico ${ }^{8}$ pode ser compreendido como sinal explícito pelas características físicas que a doença impõe. O corpo vivente alheio "porta" a descrição do fenômeno de expressão, através da face dos pacientes, que lançam realidades que podem denotar o elemento "indicador" do estado atual. O corpo físico e o corpo vivente ${ }^{9}$ representam a unidade do ser humano e permite o seu desenvolvimento (STEIN, 1933-2013; STEIN, 19171992). A análise da memória novo vivido, refere-se à participação dos pacientes nos cuidados paliativos, permitem a entrada em um novo vivido. A realidade psíquica presente (originária) “torna, o viver em cuidado e ensinamento”. Aquilo que transforma a realidade psíquica vivida, volta ao fluxo do passado, ou é abandonada. Ela entra em um novo vivido, perde a sua originalidade, mas, permanece a mesma experiência vivida. Assim, como por exemplo, a cera que se solidifica antes era líquida e depois sólida, mas ainda permanece cera, o mesmo acontece com o corpo físico. Não há um vivido individual não-psíquico (o puro vivido, com o qual lidamos na redução é não-psíquico, seja quando se torna, seja quando se tornou), a alma não pode ser separada do corpo. Há um "viver", a subida da vida e um "viver" o declínio da vida. Um "viver", não um possuir de maneira objectual, ou um constatar os estágios de desenvolvimento distinguíveis. O contínuo da vida mesma é manifestado ${ }^{10}$ para nós como tal e não como composição de traços de conexões entre pontos distintos. É manifestado também o

\footnotetext{
${ }^{7}$ Abertura interna e externa são capacidades humanas que dependem dos elementos constituintes: corporais, psíquicas e espirituais.

${ }^{8} \mathrm{O}$ corpo material de cada pessoa humana tem o aspecto puramente corpóreo (corpo físico) e difere de todos os outros.

${ }^{9} \mathrm{O}$ corpo vivente representa a alma humana que anima o corpo matéria.

10 “Gegebenheit” “datità” é uma palavra italiana que não existe no próprio dicionário italiano, portanto foi traduzida para a língua portuguesa como “manifestação”, palavra mais apropriada para definir “datità”. Essa palavra descreve o fenômeno como se apresenta no aqui e agora.
}

REVISTARELEGEN S THRÉ S KEIA-2021-UFPR 
subir a estes pontos, bem como, o desenvolvimento deles e não somente os resultados. Naturalmente existe a preocupação em tornar consciente o desenvolvimento, ou seja, de tornar objeto, o perceber do resultado, por exemplo, o diminuir das forças, quando observa-se a fraqueza e correspondente a "uma mais alta vida psíquica”, observa o desaparecer da inclinação quando ela não está mais presente (STEIN, 1917-1992, p. 142).

Ainda no vivido puro, a palavra "paliativo” esclarece à realidade psíquica do fluxo de consciência originário $^{11}$, que é um puro tornar-se. A partir daí flui o viver e o novo se acrescenta a ele em uma produção contínua, sem que seja possível perguntar por meio do que aquilo que se torna é produzido, ou seja, causado. Em nenhum ponto do fluxo de consciência o nascimento de uma fase a partir de uma outra pode ser considerado um ser causado, mas, uma surge da outra e o originário permanece na obscuridade. Enquanto as fases fluem umas nas outras, não se constitui uma série de fases interruptas, mas um fluxo de consciência único e, em contínuo crescimento. Não faria sentido, por isso, perguntar-se se há uma conexão de fases, uma conexão é necessária somente para unificar uma corrente, mas não para a continuidade do fluxo. O fluxo de consciência contínuo é formado por fases, nas quais não há uma divisão onde a nova que aparece substitui a anterior. Mas, existe somente uma fase singular contínua, onde o fluxo de consciência não tem interrupções nem sequer enrijece, o ponto permanece fixo e imutável, o novo acrescenta-se a ele, em um desenvolvimento linear (STEIN, 1922-1999).

Na análise corpo matéria, está em evidência "a submissão aos tratamentos, o choro, a emoção e o acreditar." Isso também é percebido pelo outro, que não somente visualiza "o corpo matéria sucumbido ao definhamento”, causado pela doença crônica e pelo “tratamento rígido”. O ser humano, na própria constituição corpórea, é uma coisa material como as outras, submetido às mesmas leis, inserido no âmbito da natureza material. É uma consideração abstrata, onde artificialmente prescindimos de muitas coisas que pertencem à totalidade do fenômeno ser humano. Essa consideração ajuda a colher, antes de tudo, a especificidade corporal. Na verdade cada corpo humano é especificamente diferente de todos os outros. Se compararmos ele a outros materiais que representam o ínfimo estado da matéria formada, vemos de um lado porções de uma massa, as quais não é essencial apresentar dimensão e forma, que admitem uma união com outras porções do mesmo material. Ao mesmo modo, um outro fracionamento delas em porções, de outro lado formações às quais pertencem essencialmente uma forma própria determinada e completa em si mesma, que não são porções, mas, exemplares da espécie humana, que se deixam fracionar e unir com outras para constituir

${ }^{11} \mathrm{O}$ fluxo de consciência originário é aquilo que transforma o puro viver em uma nova produção contínua. REVISTARELEGEN S TH RÉ S KEIA-2021-UFPR 
uma massa homogênea. Podemos chamar individualidade esta particularidade do corpo humano, de ser uma forma determinada, completa em si mesma, não divisível e não unificável com outras. Este fragmento corresponde a particularidade do aspecto corpóreo, apresentado nas arguições dos pacientes enquanto “corpo matéria, definhado” (STEIN, 1933-2013).

Não obstante em relação ao tratamento, na memória de análise, percepção interna, alcança o auxílio do outro, neste caso representado pela figura dos "médicos que prestam assistência paliativa”. Eles colaboram no “alívio da dor e demais sintomas físicos, aliviando o sofrimento” em todos os aspectos psicofísicos. A percepção interna dos atos manifesta a lembrança, antes não presente, que ocorre também como manifestação psíquica das propriedades ou “capacidades”. Na “alegria que transborda, a dor perturbadora”, é percebida no momento de sua realização, sem que elas sejam manifestadas em novos atos, do próprio “sofrer” e do lugar que ele ocupa no eu. Ao contrário, é possível uma objetivação das propriedades vividas, como dos sentimentos e é absolutamente necessária, por exemplo, quando se deve afirmar algo deles. Os atos que objetivam, novamente oferecem (percebem ou simplesmente indicam, entendem) e neles surge uma completa coincidência do "eu vivido” e do "eu percebido”. Para obter uma imagem completa, seria necessário percorrer cada espécie de experiência vivida. Isso pode-se fazer somente neste momento por indícios. As sensações não estão relacionadas diretamente ao eu vivido, por exemplo, a pressão, o calor, o estímulo à luz que são sentidos. Ao invés revelam para o sujeito, transformado em objeto, a "sensitividade” como propriedade psíquica constante. As chamadas sensações de sentimentos ${ }^{12}$ ou sentimentos da sensibilidade, o prazer de uma impressão tátil, a dor sensível alcançam a esfera do eu. O prazer ou a dor são “vividos” na superfície do próprio eu e ao mesmo tempo é “vivida” a própria “receptividade sensível”, como o nível mais alto ou mais externo do próprio eu (STEIN, 19171992, pp.179-180). Ainda em forma substancial, a referência ao tratamento aparece como “preciso, para aliviar a dor e o sofrimento do corpo amarelado”, a percepção do corpo se difere dos demais em sua forma, também antes do adoecimento. Para os pacientes não há reconhecimento do próprio corpo, que sofre “mudanças significativas causadas pela doença” e ao mesmo tempo não cessa a busca de compreensão do fluxo do viver.

De fato, não encontramos um corpo semelhante a outros corpos materiais e dados de fato da consciência ligados a ele, mas algo diferente, em tudo e por tudo, de todos os corpos materiais. Aquilo que chamamos corpo vivente não é simplesmente um corpo material, mas é um corpo compenetrado pela alma e, ainda é preciso indagar se nele há algo de "somente

\footnotetext{
${ }^{12}$ As sensações são sistemas sensoriais do ser humano, e o sentimento refere-se ao estado afetivo ou a uma reação.
} REVIST A RELEGEN S T H RÉ S KEIA-2021-UFPR 
corpóreo’’ e como enlaçam nele as leis da natureza material, aquelas do ser orgânico e aquelas do ser animal. Segundo o conceito tomista, o elemento que unifica o todo e ao mesmo tempo, estrutura o conjunto em uma multiplicidade de membros, é a alma. Por exemplo, não se pode explicar a diferenciação dos sentidos, na base em que o corpo possui diversos órgãos sensoriais. Ao contrário, como existem diversos sentidos como afirma S. Tomás de Aquino, por isso precisa afirmar que existem diversos órgãos sensoriais e isso, vale por todas as potências ${ }^{13}$. A alma se articula nas potências e forma o correspondente corpo vivente com a sua articulação. S. Tomás de Aquino, concebe a unidade da forma substancial, como possibilidade única. Não obstante Tomás conhece uma problemática do relacionamento entre corpo e alma.

Ele caracteriza a peculiaridade específica da alma animal e a distingue das outras duas, a alma vegetativa e a alma racional, na base da relação diferente que ela tem com o corpo. A alma humana é também vinculada ao corpo, nas suas partes inferiores, a vegetativa e a sensitiva, mas, as suas forças espirituais não estão diretamente e indissoluvelmente ligadas ao corpo vivente (elas são ligadas somente indiretamente, mediante as forças da sensibilidade sobre as funções que elas constroem). Mediante estas forças, em linha de princípio, torna acessível para ela tudo aquilo que é (STEIN, 1933-2013, pp. 73-74).

Assim como legalidade da natureza, denota vivenciar o tratamento e os cuidados paliativos como “curso natural da vida”, compreendendo o momento como "normal e sem revoltas, deixando-o fluir”. Subentende o mundo material, o das matérias formadas, como um mundo fechado em si mesmo e unitário, chamado natureza (no sentido de leis da natureza e das ciências naturais). Nele se encontram uma multiplicidade de matérias e formas próprias (as quais tradicionalmente, em um outro sentido do termo, são indicadas como naturezas). A unidade é uma unidade de ação, isso significa, que cada atividade da natureza material acontece na forma do movimento, é uma unidade do movimento. Pode-se falar de um estado global do movimento da natureza, porque tudo aquilo que nela ocorre é em relação com todas as outras ocorrências. O sentido colocado nela é o próprio agente. Na natureza não existe uma espiritualidade pessoal, as substâncias que a constituem não sabem nada de si mesmas e não são livres de determinar o próprio ser e agir. Então o acontecimento "natural” é submetido à uma rigorosa necessidade, na medida em que é deixado a si próprio (STEIN, 1933-2013, pp. 163-164).

Já para o colhimento de valor, o tratamento advém do reconhecimento de “cuidado e ajuda da família, que o cônjuge provê, o auxílio e o amparo nos momentos de vida, causados

13 Potência é a força interna humana.

REVIS T A RELEGENSTHRÉSKEIA-2021-UF P R 
pela angústia que transformam os momentos em amor e valor”. Onde somente quem "ama” colhe o "valor" de uma pessoa de maneira plena e total. O valor pessoal está ligado ao estado qualitativo da pessoa, não à sua existência, porque o valor existencial é algo a mais. Na relação recíproca entra em jogo, além do efeito causado pelo conteúdo de “valor de uma pessoa”, também a influência do movimento vital atual (STEIN, 1922-1999, p. 232). Desta forma em expressão psicofísico, está evidenciado pelos pacientes o tratamento enquanto cuidado "médico e acolhimento" que se manifesta em uma relação positiva, entre a materialidade e a espiritualidade. As arguições dos pacientes demonstram claramente o tratamento farmacológico e a relação médico-paciente. Entre os sentimentos e a expressão há uma conexão de essência e de sentido, não uma conexão causal. Na expressão corpórea que surge do sentimento, é possível viver o pleno significado. A “alegria está expressa a nível do vivido, mediante o sorriso”. Vivendo a expressão da “alegria em modo atual”, a percepção corpórea simultânea se realiza sem ter consciência disso (STEIN, 1917-1992, p. 120).

Bem como na ilusão perceptiva, a percepção de tratamento e corpo se configura no “acreditar que está tudo bem”, a partir da própria individualidade e dos demais sujeitos alheios. Essa realidade pode estar atribuída às próprias impressões e ligada às ilusões. Com base na empatia ${ }^{14}$ a própria determinação individual, pode resultar em erros. Se a empatia significasse somente a apreensão da vida psíquica alheia, deveria ser recusada, porque desta maneira a constituição do indivíduo alheio estaria somente fundada sobre a constituição do corpo físico. Ao invés, a manifestação da percepção externa de um corpo físico é pressuposto para a manifestação de um indivíduo psicofísico. De outro lado, através da única percepção externa, não se pode fazer um passo além do corpo físico, mas o indivíduo também se constitui em atos de empatia (STEIN, 1917-1992).

Além disso, na sensibilidade, o “cuidado que os médicos e a família” realizam tem espaço de gratidão, pois todas as pessoas estão "ajudando neste momento". Desta forma, está compreendida e definida a sensação e o cuidado através de uma profunda sensibilidade. O ser humano quando tocado interiormente é provocado pelo movimento reativo, ou seja, por uma percepção que acontece ao ser vivente. A sensação é uma reação. O corpo é percebido imediatamente como ser que prova sensações, isso mesmo o diferencia do mero organismo. $\mathrm{O}$ corpo vivente é corpo vivente com sensações, não somente porque percebe os estímulos exteriores, mas sente a si mesmo e é inteiramente corpo de sensações. Sente em modo

${ }^{14}$ A empatia é um processo não originário no ato do colhimento externo, apenas as experiências próprias são originárias. 
continuado, não somente superficialmente, mas quando é atingido por estímulos externos. A sensibilidade indica que o ser humano está aberto para o externo e para o interno. Assim, a alma é tradicionalmente definida como alma sensitiva (STEIN, 1933-2013).

Na vontade, em frente à percepção do outro que difere de si próprio, é possível colher as " preocupações que a família tem e a disposição para auxiliar nos aspectos básicos”, que vai além das possibilidades próprias, em um contínuo agir, que é sempre produzir algo que não está presente. Neste sentido, a vontade mesma não tem uma expressão, mas assim como o sentimento a vontade não está fechada em si mesma. Como o sentimento deixa sair de si ou motiva o ato de vontade, assim, a vontade se exprime na ação. A decisão da vontade corresponde à realização daquilo que é do querer e do fazer, por parte da pessoa em ação. A ação pode ser física no sentido de “preparação alimentar”, sendo que a ação é levada diante da inteira vontade e representa o preenchimento dela. A vontade se serve de um mecanismo psicofísico para “encher” si mesma, para realizar aquilo que é exigido, exatamente como o sentimento se serve do mecanismo para realizar a expressão. Ao mesmo tempo, o controle do mecanismo é vivido passo a passo. Há de superar ao mesmo tempo uma resistência, ou seja, o cansaço no meio do caminho se torna fonte de resistência contra o movimento. A mesma coisa acontece no âmbito puramente psíquico, onde as próprias forças podem abandonar antes da meta concluída e então é preciso recorrer à cada atividade mental para superar uma forte resistência (STEIN, 1917-1992).

\section{Codificações gerais percepção: em relação à doença}

Em relação à doença, na memória de análise originariedade e não originariedade, revela “o pensamento que não cessa”, remonta à lembrança associada às "dúvidas sobre a doença” durante a caminhada, às construções psíquicas e a sua importância. A originariedade e não originariedade $^{15}$ no mundo externo são compreendidas como algo de outra pessoa, e se manifestam de maneira originária nas próprias vivências humana. A empatia colhe aquilo que se manifesta em um dado momento. São originárias todas as próprias experiências vividas presentes, mas nem todas as experiências vividas se manifestam de maneira originária em seu conteúdo. A lembrança e a expectativa não têm objeto presente nelas, mas somente o presentificam. A não-originariedade presente se refere à originariedade que possui caráter precedente. Desta forma, a lembrança possui caráter de posição daquilo que é lembrado pelo

\footnotetext{
${ }^{15}$ Originariedade significa as próprias experiências vividas, e a não originariedade são as experiências alheias, ou seja de outros seres humanos que não se configuram as próprias originarias da pessoa.
} 
ser humano (STEIN, 1917-1992, pp. 59-60). Ainda na perspectiva corpo vivente e percepção interna de empatia Edith Stein, aponta para a experiência do corpo vivente, onde expressa a complexidade da vida, neste caso é possível acrescentar o “adoecimento" e o "pensamento duvidoso”. O corpo vivente, anima o corpo físico e presentifica à vida humana. A morte propriamente dita se configura na ausência do corpo vivente. Desta maneira, é possível compreender o ser humano como microcosmo, onde estão unidos todos os diferentes níveis, a coisa material, o ser vivente, o ser animal e a pessoa espiritual. São dimensões importantes para o ser humano e sobretudo para discutir a essencialidade do viver nos cuidados paliativos.

É possível também compreender mediante a percepção externa, utilizada para designar os atos nos quais o ser e o acontecer espaço-temporal é manifestado à pessoa de maneira viva, como algo existente no aqui e agora, endereçado à pessoa de modo originário e em sentido específico, os outros lados da percepção acontecem juntos. Sendo assim, a doença não é uma coisa manifestada à pessoa e nem é colhida na expressão de sofrimento, na qual pode ser percebida exteriormente e com a qual se apresenta junto. O confronto com o lado escolhido de uma coisa vista não está fora de lugar, mas todavia é ainda indeterminada, porque na percepção progressiva é possível sempre acrescentar novos lados à coisa originária manifestada. Cada lado dela pode ser manifestado de maneira originária. Ao contrário da expressão empática, o rosto que colhe a expressão provocada pela "dor", pode ser observada por diversos lados, mas não é possível chegar à manifestação da “dor” originária de uma outra pessoa. A empatia não tem caráter de percepção externa, mas possui algo com ela, ou seja, o mesmo objeto dela existe no momento (STEIN, 1933-2013, p. 58-108; STEIN, 1917-1992, pp. 57-58).

No fluxo de consciência, as "preocupações em relação à doença” podem ser consideradas na unidade do fluxo de consciência, nas quais o eu é sujeito da experiência vivida atual. A experiência vivida não está isolada, mas colocada no fundo de um fluxo de experiências vividas do mesmo tipo, manifestadas mais ou menos claras e distintas. O eu da experiência vivida não esteve sempre dentro dela, mas nela passou ou foi arrastado dentro por uma outra experiência vivida. Ao percorrer as experiências vividas de frente para trás se chega, passo a passo, novamente à uma experiência vivida na qual o eu que agora vive, viveu uma vez. Mesmo se não é possível mais agarrar diretamente aquela experiência vivida, mas, é necessário reportála novamente, através de uma presentificação da memória. Exatamente a ligação de todas as experiências vividas do fluxo com o presente, o eu puro ${ }^{16}$ vivente constituí a sua inviolável unidade. Agora outros fluxos de consciência estão diante do mesmo fluxo de consciência,

\footnotetext{
${ }^{16} \mathrm{O}$ eu puro é o sujeito do vivido, não é individual, mas o torna somente em contraposição ao tu e ele.
} REVISTARELEGEN S T H RÉ S KEIA-2021-U F P R 
aquele do tu e do ele estão em frente ao fluxo do eu. A especificidade das experiências vividas e a alteridade estão baseadas sobre as experiências vividas do sujeito ao qual pertencem. Não são somente outros, mas são também diversos, porque cada um tem o seu conteúdo de experiências vividas. Como cada singular experiência vivida de um fluxo de consciência está caracterizada especificamente pela posição no contexto global de experiências vividas, ela está caracterizada não somente pelo seu pertencer ao eu. Mas, também de um ponto de vista qualitativo, enquanto experiência vivida deste e de nenhum outro eu. Em força do conteúdo de experiências vividas, os fluxos de consciência estão distintos qualitativamente (STEIN,19171992, p. 101).

Para a expressão da alma espiritual, expõe “a vida, a doença e os vícios”, é possível nessa perspectiva perceber a fraqueza do corpo e o agir do espírito nele. Na verdade, de um ponto de vista puramente fenomênico, deve ser salientada uma dependência da vida psíquicoespiritual, pela constituição do corpo vivente e pelo estado no qual ele se encontra em um determinado momento. A “doença e a fraqueza do corpo”, as alterações das suas funções normais, provocam uma inibição e uma mudança da vida psíquico-espiritual. É um problema individual em qual medida os influxos podem ser diretamente contrastados a partir do nível espiritual, ou seja, mediante esforços de vontade ou mediante um reforço, que vem de fontes espirituais e não mediante um tratamento do corpo (STEIN, 1933-2013, p. 123).

Em relação à memória de análise “consciência”, torna-se também evidente a consciência dos "vícios e a interrupção” dele, após a descoberta da “doença oncológica” e demais doenças. A consciência somente é manifesta, a partir da “dor pela perda da saúde”. A função da alma é a consciência, com a qual o ser humano percebe um chamado, que aprova ou condena as ações passadas e presentes. O chamado é entendido como potência, hábito e ato. A consciência material ou repreensiva percebe a exigência de um determinado comportamento, em um momento determinado e em determinadas circunstâncias. Ela exige a livre submissão da vontade. A consciência que julga, não somente expressa julgamentos sobre a ação, mas diz algo do próprio ser, a “boa” ou “má” consciência não é ela mesma “boa ou má”, mas, testemunha o modo de ser da alma. A consciência não fornece a imagem global daquilo que a pessoa deve ser, como critério para todo o comportamento. A alma condena a ação de "fumar e beber" e institui o chamado consciência (STEIN, 1933-2013).

Também na memória “autoformação”, a mudança de vida após “o diagnóstico de câncer", pode ser compreendida pela constituição do ser humano como corpo vivente, ele assume uma forma pessoal. Isso significa que nele mora um eu consciente de si mesmo e com 
o olhar voltado ao mundo, um eu livre, que graças à sua liberdade pode dar forma ao corpo vivente. Um eu que vive a partir da própria alma e que, mediante a estrutura essencial da alma, forma espiritualmente a própria vida atual e o ser psicofísico permanente (STEIN, 1933-2013).

Em relação ao corpo matéria individual, manifesta o “corpo adoecido”, a individualidade e a particularidade do corpo humano confere uma forma determinada, completa em si mesma, não divisível e não unificável com outras. Por isso, o “corpo material” declarado nas arguições, passa pela “corporeidade e pela individualidade”, ou seja, a maneira pela qual o vivido se expressa. E as diversas espécies de dados sensíveis externos se juntam à manifestação sensível do próprio corpo vivente, que pode ser definido como “sensibilidade interna”, porém, a interioridade não é única. A ela está estreitamente ligado o estado emotivo interno, que surge das impressões externas. Aquilo que se torna e denomina sensações de sentimento é ordenado nas categorias polares fundamentais, de prazer e desprazer. É exatamente o ponto de passagem do estímulo às reações, ao ser empurrado, atraído e rejeitado (STEIN, 1933-2013, pp. 45-72).

Outrossim, refere-se ao organismo vivente, mediante o impacto do "diagnóstico”, a aplicabilidade do "cuidado, o sentido da vida" e da responsabilidade com aquilo que constitui o ser humano, para além do corpo físico. O corpo com a sua forma determinada, articulada e completa em si mesma é considerado uma realidade que se mantém junto interiormente. A forma exterior é formada do interno. O corpo carrega consigo toda a sua propriedade, mediante o processo formativo progressivo. Na verdade, ele passa por transformações, onde a formação do interno é o peculiar modo de ser do vivente. Aquilo que forma do interior é indicado por S. Tomás de Aquino como forma interior, que ele também chama de alma. O processo de formação tem uma finalidade, que tende à uma forma determinada e totalmente desenvolvida e articulada, ativada no interno. Para se manter na forma e ao mesmo tempo ela tende para algo que vai além de si. A forma interior qualifica o todo e, é algo de qualitativamente determinado. Ela é ao mesmo tempo uma espécie de força vital que opera no processo de formação (STEIN, 1933-2013).

No ser pessoa, os apontamentos estão delimitados acerca da "vida, doença e das mudanças nas relações" humanas, considerando que o homem nasce em uma comunidade chamada família e entrelaça as relações no curso da vida. Após "o diagnóstico da doença", a vivência da doença “abala e rompe os laços”, a "temporalidade do passado sem a doença e a presença dela reiteram o estado atual das relações”. A existência do homem no mundo e na vida são comunitárias. Não são relacionamentos externos, que chegam a um ser existente em si mesmo e para si mesmo (STEIN, 1933-2013). 
Na forma, “força e matéria”, o "tempo de investigação da doença” aponta para o corpo matéria constituído pelos “órgãos”. A vida humana necessita de força interna para articular a matéria corpórea. Na verdade, a indagação referente aos “órgãos considera o tumor presente e as reações corpóreas”, que interferem na "vida da pessoa e na equipe de saúde, que busca manter o equilíbrio vital”. O corpo enquanto forma determinada, completa e articulada mantém junto a realidade interna. A formação do interno é aquilo que diferencia os organismos das outras coisas materiais, “coisas mortas”, a matéria sem forma não é impossível, porque ela recebe a existência somente graças à forma. Entretanto, a forma vivente começa a agir em uma matéria já formada, através dela recebe a vida e, é encaminhada a incorporar progressivamente novos materiais para estruturar o organismo e formar. Dependendo das condições materiais, a forma pode operar de maneira pura e sem obstáculos, com isso pode levar o organismo à sua forma completa. Depois deste trabalho de formação, a força vital, se alimenta de si própria e acaba por consumir. Por isso, no organismo há um ponto de máximo desenvolvimento e depois disso o processo de formação não pode mais acontecer. Ele chega a um declínio, ou seja, a um progressivo apagar da força formante e correspondente ao aumento da matéria não mais formada como matéria vivente, até a completa diminuição da vida. A forma vivente, ou seja, a alma faz do corpo humano um organismo. Quando nele não há mais a vida, ele é somente uma coisa material como as outras (STEIN, 1933-2013).

A memória “percepção externa”, revela a preocupação, o reconhecimento da necessidade de "amparo à família", traduz as dificuldades vivenciadas pelos pacientes e a dor originária. Assim, a percepção externa da “dor”, corresponde aos atos nos quais o ser e o acontecer espaço-temporal se manifestam em algo de existente agora, originário em sentido específico. A “dor” não é uma “coisa” que se manifesta na mesma maneira como ela é colhida, como expressão de sofrimento e de percepção externa. Ao contrário, a expressão de “dor” externalizada por um rosto humano, pode ser vista por várias pessoas, através do aspecto modificado da face. Quando colhida empaticamente a expressão da “dor” no rosto de uma pessoa, pode ser observada por todos os lados. Mas, nunca é possível colher a “dor” e a própria expressão de outra pessoa de maneira originária. (STEIN, 1917-1992).

Em relação à doença a "perda da saúde, os aborrecimentos da vida", de um ponto de vista puramente fenomênico, decorre de uma dependência da vida psíquico-espiritual, pela constituição do corpo vivente e pelo estado momentâneo da pessoa. A doença e a fraqueza do corpo, as alterações das funções normais, provocam uma inibição e uma mudança da vida psíquico-espiritual. É um problema particular, a medida em que influxos podem ser diretamente 
rejeitados, a partir do nível espiritual, mediante os esforços da vontade, ou por um reforço que vem de fontes espirituais e não do tratamento do corpo (STEIN, 1933-2013, p. 123). Ainda em movimento corporal, a percepção do “corpo adoecido” revela o movimento e a transformação da corporeidade que envolvem a vida, a alma e o espírito. Ao considerar, antes de tudo o movimento do corpo inteiro, aparece como uma singular oposição. São encontrados movimentos com os quais o corpo segue evidentemente suas próprias leis e outros com os quais é submetido a leis externas. A diferença dos movimentos se torna evidente quando o curso normal de um ser humano é interrompido por uma doença. O funcionamento normal do corpo obedece à uma própria legalidade que parte do centro. O ser humano que adoece, é submetido a um impedimento do movimento, que fenomenicamente é imposto a ele pelas causas externas, mesmo assim, ele tenta conservar o próprio movimento. Neste caso, ocorre um cruzamento de dois diferentes movimentos, que fenomenicamente se diferencia do cruzamento de dois movimentos de corpos puramente materiais (STEIN, 1933-2013, p. 48). Em cada paciente ocorre um movimento fenomênico do interno para o externo, que obedece às leis naturais. A doença se manifesta como movimento oposto ao movimento natural, cada paciente em cuidados paliativos vê, sente e percebe a doença de uma determinada maneira. Existem vários fatores internos e externos, que podem influenciar a qualidade de vida dos pacientes em cuidados paliativos. Dentre os fatores estão a relação pessoal, relação com a família, com a equipe de saúde, com a doença, com o tratamentos e com os sentimentos. E as questões relacionadas à aquisição da doença, que podem se configurar em sentimentos de não merecimento e de não pertencimento à condição atual, dentre outros.

Para a memória de análise “domínio”, ainda em relação à especificidade “doença”, a percepção quanto à “vida anterior e os vícios em relação ao momento atual”, considerando a interrupção dos “vícios” imposta pela doença e hospitalização. Isso não se deve à vontade espontânea, porque ela prevalece incessante. No processo formativo espontâneo, somente a vontade pode intervir de modos diferentes, exercendo poder sobre a expressão, ou sobre a vida psíquica mesma. A passagem do evento puramente psíquico à expressão do corpo, é algo que pode ser submetido ao domínio da vontade. O ser humano que detém domínio sobre a própria expressividade, tem um aspecto corpóreo expresso totalmente diferente daquele que manifesta livremente a interioridade. A isso corresponde também uma transformação psíquica, mas, não com certeza a mudança de uma pessoa. A transformação somente é possível onde a vontade age em um nível mais profundo, ela busca reprimir as emoções no primeiro movimento e procura despertar aquelas opostas. Temos, então, uma espiritualização da alma, dominada pelo 
livre agir (STEIN, 1933-2013, pp. 125-126). Em relação aos cuidados paliativos, a responsabilidade do livre agir é necessário ao paciente para transformar a realidade atual de tratamento e doença, em momentos de valor.

Já em propriedades pessoais, o indicativo expressa as "preocupações com a vida e morte, sobretudo as questões financeiras em relação a família”. As questões “sociais, econômicas” interferem na vida de forma direta, ocasionam “interrupções dos planos e temor”, tudo isso em decorrência do "estado de saúde e da hospitalização", exigem adaptações necessárias à dura realidade da vida. Os sentimentos são "vividos" na própria pessoa não somente como presentes, mas também como constituídos de maneira determinada. Eles manifestam propriedades pessoais. É possível uma objetivação dos sentimentos, enquanto propriedades vividas. Esta objetivação dos sentimentos é absolutamente necessária, quando por exemplo se deve afirmar algo deles. Estes atos objetivantes, contém a percepção de uma completa confluência do eu vivido e do eu percebido. Para obter uma imagem completa, seria necessário percorrer cada espécie de experiência vivida dos pacientes em cuidados paliativos, neste caso foi possível apenas um recorte das percepções objetivas. O medo de morrer e deixar a família sem suporte financeiro é a principal preocupação deles. (STEIN, 1917-1992, pp. 179-180).

\section{Codificações gerais percepção: em relação aos sentimentos positivos e negativos}

Em relação aos sentimentos positivos no sentido externo e interno, os pacientes expressam a "não preocupação e não tristeza pela condição de doença e dos cuidados paliativos", neste aspecto são consideradas as diversas espécies de dados sensíveis externos, que se juntam à manifestação sensível do próprio corpo vivente que pode definir a sensibilidade interna. A interioridade não é, porém, a única, a ela está estritamente ligado o estado emotivo interno que surge das impressões externas. As sensações de sentimento, é ordenado nas categorias fundamentais de prazer e desprazer. É exatamente o ponto de passagem do estímulo às reações receptivas dos "cuidados paliativos" e manifesta também a avaliação instintiva daquilo que provém do externo como útil ou danoso (STEIN, 1933-2013, p. 72).

Além disso, na análise da memória o processo de informação do corpo, representa o "sentimento de contentamento e não depressão pela doença”, expressa a atitude de enfrentamento ao tratamento, provoca uma ação que corresponde ao processo de "informação do corpo" e exige dele a criação de centros. A partir dos quais, ele possa se manter, se sustentar, se movimentar e enfrentar aquilo que se vem do externo. Na medida em que o processo de “informação” se completa, o organismo se apropria de si mesmo, contudo, nunca deixa de ser 
corpo material submetido às condições dos acontecimentos materiais (STEIN, 1933-2013, p. 53).

Em vontade e força humana, a vida se desvela em "crescimento pessoal”, ou seja, "conhecimento que perpassa a doença". Sendo necessária uma determinada força vital ${ }^{17}$ que pode consumir-se até exaurir-se, não somente nas atividades corporais, mas também nas espirituais. Em cada ato espiritual, o ato da vontade usa da força existente, isso é um exercício de força. Diante deste ponto de vista é possível aproximar-se da própria e particular unidade da natureza humana. A relação entre a vontade e a força empregada não é diretamente reconhecível e compreensível. Por exemplo, o andar e o "estar de pé" para o paciente é considerado uma força física, talvez isso não seja nem consciente. Com certeza, há uma vontade própria de colocar-se em movimento determinado, direção e permanecer constantemente em movimento. Mas, o modo em que a vontade coloca o corpo em movimento, não faz parte do próprio vivido consciente e do prefixar o objetivo de realização. Somente a consciência de poder, de domínio do próprio corpo e sobre o movimento é incluída. A própria decisão original, motivada pelo ponto de vista do conhecimento em base de objetivas considerações, não é inteiramente racional, porque não leva em conta a capacidade física. O homem pode estabelecer objetivos, baseados em reflexões puramente espirituais, mas, não pode alcançá-los sem a colaboração do próprio corpo. A avaliação da própria força é um ato espiritual, que pode entrar no contexto do conhecimento fundado e estabelecer um objetivo. Sendo assim, os “estados vitais” são estados gerais do indivíduo psicofísico, que influenciam o curso de toda à vida e todos os vividos (STEIN, 1933-2013, pp. 172-173). Ainda na direção das impressões externas e internas, as expressões acerca do "amor próprio em primeiro lugar" e posterior exposição verbal a exterioridade pelo "amor", expõe a manifestação aos outros de uma abertura, especificamente humana. É possível encontrar no ser humano uma abertura, mediante os sentidos, para as impressões externas, internas e as reações de impressões externas, com movimentos e atos instintivos. Aqui é possível efetivamente experimentar interiormente em si próprio, o perceber sensitivo e o agir reativo. Isso é possível, porque os seres humanos não são seres meramente sensitivos, mas, capazes de conhecimento espiritual. O ser humano em virtude da própria espiritualidade, consegue acatar em si o aspecto puramente humano. Diante das limitações e fragilidades, o ser humano, pode apresentar reações diversas, únicas e irredutíveis, até mesmo em seu aspecto primitivo. Cabe a ele colher as melhores qualidades sensíveis. Diferente do

\footnotetext{
${ }^{17}$ Força vital, indica a energia necessária para aceitar e viver qualquer conteúdo. Na esfera vital existe a força vital sensível e força vital espiritual. A força vital espiritual é condicionada pela força vital sensível, na verdade quando diminui o vigor corpóreo diminui também o espiritual (STEIN, 1933-2013; STEIN, 1922-1999).
} 
animal, que reage aos estímulos por instinto, o ser humano consegue configurar as impressões sensíveis, como objetos incluídos em um mundo de coisas experimentáveis (STEIN, 19332013, pp. 103-104).

Assim, como nas sensações externas e internas, as sensações de "alegria e bem-estar " externas e internas se caracterizam em diversas espécies de dados sensíveis externos, juntos com a manifestação do próprio corpo vivente, que se pode definir como "sensibilidade interna”"18. Para S. Tomás de Aquino, existe ainda um outro “ser interno”, um permanecer das impressões anteriores recebidas, que se manifesta na procura de algo que não está presente e em uma avaliação instintiva daquilo que aproxima do externo como útil ou danoso. Ao indicar algo que corresponde às disposições de ânimo humano, é possível considerar uma disposição de ânimo duradoura, sobretudo em comparação com outros animais. Existe uma série de categorias, nas quais se enquadra a multiplicidade da vida psíquica atual. Neste caso, não se pretende de modo algum demostrar a relação completa entre elas. A vida em sua atualidade é caracterizada por um contínuo vai e vem de estímulos externos, estados emotivos interiores, impulsos instintivos. Atrás desse vai e vem há, porém, algo de permanente, que torna possível a atualidade. Os atos são manifestações de potências, faculdades ou “forças”. Têm a sua raiz na alma, que é o princípio de todas as manifestações e atividades vitais do ser vivente (STEIN, 1933-2013, p. 72).

No movimento orgânico, expõe a percepção de vida caracterizada pela “utilidade” e atividade vital que corresponde ao movimento de proceder “ações de tarefas cotidianas”, está representado pelo “sentimento de contentamento". Se trata de um movimento interno que se direciona para o externo, que manifesta a utilidade da vida, em decorrência de um corpo percebido como "bom". Ao passo que a ciência médica faz referência ao corpo que muitas vezes não se configura da mesma maneira na qual é percebido pelos pacientes, mas ao contrário, o corpo que configura como "bom" aos olhos dos pacientes, pode representar como "ruim" na expressão patológica. É preciso entender aquilo que é próprio do corpo humano como organismo, a "informação" da matéria mediante a "forma” vivente interna, a aquisição dos materiais necessários, o cooperar das partes no todo e a geração de outros da própria espécie. Todo processo, que chamamos vida é atividade em movimento. O organismo está em constante movimento, em movimento interno e movimento do interno verso externo. Assim, é entendido o fenômeno do movimento que o caracteriza, segundo as suas próprias leis. Com o próprio movimento, o organismo segue a lei da própria forma interior. O processo de formação do

\footnotetext{
${ }^{18}$ Sensibilidade interna é o estado emotivo interno, que surge das impressões externas.
} REVIS T A RELEGEN S TH RÉS KEI A-2021-UFPR 
corpo, precisa que sejam criados nele centros, a partir dos quais ele se mantém, se sustenta e se movimenta e enfrenta aquilo que se aproxima dele vindo do externo. Na medida em que o processo de formação avança, o organismo empodera de si próprio. Contudo, nunca deixa de ser corpo material e de submeter às condições dos acontecimentos materiais (STEIN, 19332013, p. 53).

Ainda em relação aos sentimentos positivos na memória de análise “força”, traduz a vida como de "alegria e força que emana da família, cônjuge, filhos e netos, como sustento para o momento de vida”. Pode-se dizer que a vida da alma, entendida como psique, aparece submetida à ação de diversas forças, a força sensível, que se apresenta em relação à apreensão dos dados sensíveis e nos impulsos sensíveis e a força espiritual, totalmente nova e diferente da primeira, mas que pode abrir-se somente em colaboração com a força sensível. A força sensível tem as suas raízes na natureza e isso justifica a ligação entre natureza, corpo e psique. O lado corpóreo da psique corresponde ao espiritual, mediante o qual a psique se abre ao mundo objetivo (STEIN, 1922-1999, p. 15).

Para a análise avaliação de si, o desejo de encontrar, de rever "os filhos, os amigos e a família, revelam o entusiasmo presente na vida de contentamento e alegria” expresso pelo sentimento positivo. O conhecimento de si manifesta como um importante instrumento de avaliação de si próprio. Como o vivido de valor é fundante para o próprio valor, ao mesmo tempo os novos valores adquiridos na empatia, se abrem sobre os valores desconhecidos da própria pessoa. Cada ato com o qual são colhidas pessoas de tipo diferente, pode tornar-se o fundamento de uma comparação de valores. $\mathrm{O}$ ato anterior e posterior manifestam os valores geralmente não observados, se aprende a estimar a si próprio de maneira correta, pelo fato que "vive-se" si mesmos como pessoas mais ou menos válidas, em comparação com as outras. É possível compreender também os elementos necessários para realizar a motivação, eles estão manifestados nos impulsos exigidos pela motivação, que podem ser internos ou externos. No estado de frescor no qual o fluxo do vivido pulsa rapidamente, o impulso interno arrasta um pensamento para outro em uma conexão motivada. Somente se o impulso interno falha, é necessário um motivo que forneça energia, ou seja, um impulso emotivo, para tornar eficazes as motivações intelectuais a partir de uma quantidade de força vital (STEIN, 1917-1992; STEIN, 1922-1999).

Ainda na especificidade “alma e pessoa”, é possível encontrar na humildade o "potencial para amar o outro com sinceridade e a capacidade de perdão”. E, consequentemente, vislumbrar na pessoa puramente espiritual o valor que sente e “vive” nele, o nível correlativo à sua essência. 
Este sentimento não pode tornar-se nem mais profundo nem menos profundo. Um valor, para ele excluído, permanece ainda um valor sentido que não está perdido. Também um indivíduo psicofísico não pode nunca ser levado para um valor por meio do hábito, porque falta para ele o nível pessoal correlativo. Os níveis da pessoa não se podem “desenvolver” ou “deteriorar”, mas podem somente manifestar-se ou não no curso do desenvolvimento psíquico. Isso vale, seja para a causalidade intersubjetiva como para a intrassubjetiva. Os pacientes em cuidados paliativos de certa maneira são atingidos externamente e internamente. A família pode ser considerada o elemento que constitui o externo. As relações familiares são diferentes, bem como os valores internos e externos. Para alguns membros da família, aquilo que muitas vezes determina algo de importante, para outras não são sequer lembrados, isso decorre da própria individualidade humana. Para alguns pacientes, a lembrança do vivido passado pode estar presente na memória e, o sentimento de “perdão”, para muitos deles pode fazer sentido e facilitar as relações intersubjetivas. A condição do adoecimento, talvez tenha sido o meio utilizado por alguns pacientes para repensar a própria personalidade. A pessoa não está submetida ao contágio do sentimento, pelo contrário, ele serve para revelar o verdadeiro conteúdo da personalidade. Os relacionamentos nos quais um indivíduo cresce, podem alimentar nele um desprezo para certos comportamentos, que não corresponde à nenhuma propriedade original e pode ser removido por meio de outros influxos. Quem foi educado segundo os “princípios morais” e se comporta segundo eles, quando volta o olhar para si, terá a percepção satisfeita de um homem virtuoso. Até que um dia, mediante uma ação que brota do profundo da interioridade, "viverá” como uma pessoa completamente diversa daquela que pensava de ser até então (STEIN, 1917-1992, pp. 193-194).

No indivíduo psicofísico-espiritual, revela a "harmonia da vida”. Pela constituição psicofísica entende-se o corpo vivente alheio como centro de orientação do mundo espacial, no qual o eu pertence a ele como um sujeito espiritual, onde todas as percepções externas se realizam em atos espirituais. Ao mesmo modo em que cada ato de empatia em sentido literal penetra no reino do espírito. Como a natureza psíquica se constitui em atos de percepção, assim um novo reino de objetos se constitui no sentir o mundo dos valores, na alegria a pessoa tem de frente a si algo de alegre, no medo algo de assustador, na angústia algo de ameaçador. Os mesmos estados de ânimo têm o seu correlato objetivo, para a pessoa serena, o mundo é imerso em um esplendor. Tudo isso é manifestado junto aos atos de sentimento como pertencentes a eles. O acesso a estas experiências vividas é garantido em primeiro lugar pelos aparecimentos de expressão. Considerados provenientes das experiências vividas, possui contemporaneamente 
uma extensão do espírito no mundo físico, ou seja, um tornar-se visível do espírito no corpo vivente pela realidade psíquica, do indivíduo psicofísico (STEIN, 1917-1992, pp. 169-170).

Assim como no acolhimento, aparece o reconhecimento das ações como o "perdão, o reparar os erros e os pedidos de desculpas”, tudo isso é necessário no acolhimento interno dos próprios “atos de vida”. A constituição do indivíduo alheio é a condição para a plena constituição do próprio indivíduo, algo de similar se encontra também ao nível superior. Considerar a si mesmo na percepção interna e o próprio eu psíquico e suas propriedades, significa ver a si mesmo como é, e o outro como o outro o vê. "Amar e odiar”, querer e fazer, alegrar e entristecer, tudo isso é expresso em certo sentido pela consciência, sem que isso seja acolhido e sem que seja objeto. Tudo isso, é feito sem nenhuma mediação, não é transformado em objeto da própria atenção nem de observação, e nem mesmo da avaliação. Ao contrário, tudo isso, é feito a respeito da vida psíquica alheia, que graças à sua conexão ao corpo físico percebido, está em frente ao objeto desde o início (STEIN, 1917-1992, p. 165-166).

Ainda considerando a especificidade dos sentimentos positivos em constituição do mundo real, prova "a família e o lar como lugar de paz e de conforto que remete ao passado e ao momento atual.” A percepção do passado se junta ao presente. Assim, como o mundo percebido é dado, manifestado empaticamente é o mesmo mundo, visto diversamente. Mas, não é somente o mesmo visto de lados diferentes como na percepção originária. Um olhar que remete de um ponto de observação ao outro, em contínuas variedades de aparecimentos, nos quais o precedente motiva aquele sucessivo e o seguinte substitui aquele que acabou de passar. A passagem de um ponto de vista pessoal ao outro se atualiza naturalmente ao mesmo modo. Mas, o novo ponto de vista não substitui aquele velho, porque detém eles, ambos ao mesmo tempo. O mesmo mundo não se "mostra” simplesmente em um modo e depois em um outro, mas, em ambos os modos ao mesmo tempo. Se apresenta em modo diverso não somente de acordo com o ponto de vista do momento, mas, também de acordo com a determinação do observador (STEIN, 1917-1992, p. 134).

Na memória de análise, em relação aos sentimentos positivos na "gratuidade”, está expresso o "sentimento de contentamento, bem-estar e família" tudo isso é "gratuidade humana” e revela a transcendência do homem. Porque na percepção de uma coisa (oração e bem-estar), que desperta a confiança na existência, o conhecimento de um estado de coisas cria a convicção da sua efetiva consistência, a capacidade de acolher as qualidades positivas de uma pessoa e desperta admiração por ela. As tomadas de posição espontâneas são como as tomadas de ato, trata-se de algo que é “recebido”. Não é possível realizá-las ao mesmo modo de um 
endereçar-se, que depende da vontade e da liberdade e não dá a possibilidade de decidir, em favor ou contra elas por prazer. Isso ocorre por dois motivos, porque a tomada de posição espontânea cabe à objetualidade, para a qual tem valor e, é a objetualidade que pede a tomada de posição. Ela não é simplesmente causada, mas fundada. Se é possível decidir contra a tomada de posição espontânea seriam violadas as normas evidentes. O outro motivo é representado pelo fato que as tomadas de posição espontâneas não se apresentam antes do comparecimento da objetualidade, mas existem sobre o fundamento de tomadas de ato, sem uma escolha preliminar, elas tomam posse do ser humano. De outro lado, não é possível consegui-las se não apresentam por si mesmas (STEIN, 1922-1999, pp. 80-81).

Bem como em persistir, está representado pela percepção do período de vida que expõe o “pensamento positivo e não negativo”, essa nova fase de vida enquanto o novo se produz, há um persistir “vivente do transcorrido", na maneira em que uma fase do fluxo contém ao mesmo tempo aquilo que se torna e o que já se tornou. Mas, o vivente ainda hoje é vivido como ainda vivente. Por isso, se distingue propriamente por aquilo que entra agora no viver, mediante uma indicação que remete a lembrança do passado. Quando o transcorrido ainda vivente, se une ao viver como algo que nasce daquele momento, formam-se as unidades do vivido. Essa unidade se fecha até o momento em que não se acrescentam a ela novas fases (STEIN, 1922-1999, pp. 45-46).

Já em consciência e psíquico, a "incerteza" deles é a nova dimensão que os "cuidados paliativos" tomam e, pela via das médicas "doutoras", que estimulam o acreditar no cuidado. É possível compreender pelos estados vitais dos seres humanos conscientes, que costumam manifestar-se conforme à consciência deste estado e do ser vivido, que é um sentimento vital. Mas, é possível também que os estados vitais se apresentem, sem revelar os sentimentos vitais. É provável "não acreditar ou desconfiar" e eventualmente revelar o estado às outras pessoas, através do próprio aspecto exterior, sem ter plena consciência disso. Em um estado de excitação, ou durante uma atividade de empenho às quais é dedicada total atenção, é concebível a não consciência da própria condição. Somente com o cessar do esforço anterior no qual se manifestava um estado de total desconfiança e esgotamento, agora consciente desta manifestação, que já estava presente anteriormente e com este esforço, houve gasto de energia de maneira desproporcional. A sucessão dos estados vitais é algo de transcendente em relação ao viver e se manifesta nele. Torna-se consciente em um sentimento vital, então este tornar-se consciente não deve ser confundido com o viver um conteúdo imanente, ou com a consciência do viver, que é um momento constitutivo (STEIN, 1922-1999, p.56). 
Ainda na percepção do corpo vivente, ao exprimir as sensações próprias do ser humano mediante a "dor e o sofrimento que advém dos sintomas da doença", ainda encontra na vida algo de "alegria” que não está manifestada pela "tristeza" do momento. Percebe a importância de "vivenciar a doença” e questionar o próprio eu para obter crescimento pessoal, ou seja, a real serventia da vida. Não há possibilidade de questionar o "porque essa doença" não está presente no outro. Na percepção do corpo vivente temos uma manifestação originária dos próprios campos sensoriais. Além disso, na percepção externa do corpo físico eles são manifestados naquele modo totalmente peculiar, no qual junto aquilo que é percebido, pode haver aquilo que não é percebido. Neste modo, estão presentes campos sensoriais do outro corpo vivente alheio “visto”, como corpo vivente. Na percepção da coisa encontramos este tipo de manifestação que Stein (1917-1992) chama de com-originariedade ${ }^{19}$. Estão manifestados também os lados escondidos e o interno, ou seja, a inteira coisa é vista. Mas, a manifestação de um lado implica tendências que procedem para novas manifestações e os lados antes escondidos são percebidos em sentindo pleno, aquilo que antes era como originário é manifestado em modo originário (STEIN, 1917-1992, pp. 125-126).

Em análise da memória tonalidade dominante, a referência está voltada às lembranças “das perdas, dos sonhos e planos não concretizados”. A análise aponta o sentimento de fracasso, a presentificação da lembrança viva na memória. As lembranças, os atos do pensamento e todos os atos se manifestam de fato, se realizam em modos determinados mediante a particularidade momentânea do sentimento vital, sem ser retroativa sobre o sentimento vital mesmo. Porém, perto disso há outros vividos, que participam em modo particular do sentimento vital e se ligam por eles mesmos ao estado do sentimento. Trata-se dos movimentos do sentimento ou sentimentos. A profundidade do sentimento depende da intensidade do valor e a sua força específica dependem da natureza particular do valor. A força é maior ou menor, enquanto o sentimento pode ser caracterizado como desmotivado e irracional, isso se explica pelo efeito sentimento vital que é manifestado. Os vividos são ao mesmo tempo algo que invade a própria pessoa e se insere no próprio sentimento vital. Trata-se de um novo fluxo que do externo se expande no fluxo vital, agita, influencia o curso posterior e o define com nuances particulares. Então, a natureza do efeito pode ser diferente de acordo com a natureza do sentimento. Cada sentimento, que origina com uma determinada força, faz avançar mais rapidamente o fluxo enquanto continua a fluir e o caracteriza com uma tonalidade mais clara ou mais escura. $\mathrm{O}$ modo no qual o sentimento vital muda de intensidade depende do caráter específico do vivido

\footnotetext{
${ }^{19}$ A com-originariedade é meio pelo qual são manifestados os lados escondidos e o interno da pessoa humana.
} REVISTARELEGEN S THRÉSKEIA-2021-UFPR 
que cada vez age. É motivado de acordo com o seu conteúdo e mediante ao objeto direcionado. Pode também ser compreendido como ato perceptivo, enquanto manifestação da "lembrança e fantasia”. Atos não originários fazem parte de uma vivência passada ou ainda não realizada. Se tornam atos originários, por meio da presentificação da “dor, da lembrança e das perdas por aquilo que foi e por aquilo que não foi realizado" (STEIN, 1922-1999, p. 106-107; STEIN, 1917-1992, pp. 59-61).

\section{Considerações finais}

A análise das percepções dos pacientes em cuidados paliativos está fundamentada no exame das três obras de Edith Stein e no método fenomenológico steniano. A pesquisa qualitativa permite compreender a complexidade e os detalhes das informações, por meio das arguições dos pacientes, pelas vivas expressões de linguagens, colhidas no âmbito das relações. As narrativas dos pacientes, as percepções e as relações estabelecidas com a equipe de saúde, família e amigos, foram apresentadas nos resultados de pesquisa. A partir da percepção individual de cada paciente, foi possível estabelecer as codificações gerais, especificadas em relação ao tratamento, à doença e aos sentimentos positivos e negativos. O resultado minucioso da pesquisa e detalhado pelos pacientes, entrelaçadas com a teoria, permitiu analisar as percepções dos pacientes em cuidados paliativos, considerando o momento de vida, o próprio conhecimento deles e a centralidade. Na perspectiva dos cuidados paliativos a pessoa é a centralidade.

A análise da percepção dos pacientes, indicam que eles são os possíveis meios para estabelecer as relações intersubjetivas e intrassubjetivas nos cuidados paliativos, facilitando o cuidado à equipe de saúde, à família e os demais envolvidos. A realidade interna, as experiências vividas, a maneira de perceber a si próprio e os outros, estão fundamentados nas memórias de análise. De modo geral a teoria em diálogo com a realidade percebida pelos pacientes, possibilita compreender as relações estabelecidas, as concepções dos pacientes em cuidados paliativos que representam a gratuidade, o cuidado, a aprendizagem e o respeito entre as pessoas. Quanto aos limites da pesquisa, destaca a impossibilidade de apreender a totalidade das percepções dos pacientes, os tratamentos, a doença, os sentimentos positivos e negativos, isso ocorre em decorrência das mudanças de intensidades do fluxo do viver.

\section{REFERÊNCIAS}

ANDRADE, Celana Cardoso. HOLANDA, Adriano Furtado. Apontamentos sobre pesquisa qualitativa e pesquisa empírico-fenomenológica. Estud. psicol. Campinas, v. 27, n. 2, p. 259- 
268, 2000. Disponível em: http://dx.doi.org/10.1590/S0103-166X2010000200013 Acesso em: 9 ago. 2020.

BICUDO, Maria Aparecida Viggiani (org.). Pesquisa Qualitativa. Segundo a visão fenomenológica. São Paulo: Editora Cortez, 2011.

BRASIL. Conselho Nacional de Saúde. Comissão Nacional de Ética em Pesquisa. Resolução n. 466, de 12 de dezembro de 2012. Disponível em: https://bvsms.saude.gov.br/bvs/saudelegis/cns/2013/res0466_12_12_2012.html Acesso em: 20 dez, 2019

GALVAO, Taís Freire; PEREIRA, Mauricio Gomes. Revisões sistemáticas da literatura: passos para sua elaboração. Epidemiol. Serv. Saúde, Brasília, v. 23, n. 1, p. 183-184, mar. 2014. Disponível em http://scielo.iec.gov.br/scielo.php?script=sci_arttext\&pid=S167949742014000100018\&lng=pt\&nrm=iso . Acesso em:17 mar. 2020.

INSTITUTO NACIONAL DO CÂNCER-INCA. Cuidados Paliativos. (Brasília, DF): Instituto Nacional do Câncer, 2020. Disponível em: https://www.inca.gov.br/tratamento/cuidados-paliativos Acessado em 07 nov. 2020.

MARCONI, Marina de Andrade; LAKATOS, Eva Maria. Metodologia científica. 6 ed. São Paulo. Atlas, 2011.

MINAYO, Maria Cecília de Souza. O desafio do conhecimento: pesquisa quantitativa em saúde. 8 ed. São Paulo: Hucitec, 2004.

SALDAÑA, Johnny. The Coding Manual for Qualitative Researchers. London: Sage, 2013.

STEIN, Edith. La struttura della persona umana: corso di antropologia filosofica. Trad. Michele D’Ambra. Roma: Città Nuova, 2013. (Original publicado em 1933).

STEIN, Edith. (n). Psicologia e scienze dello spirito: contributi per una fondazione filosófica. Trad. Anna Maria Pezzella. Roma: Città Nuova, 1999. (Original publicado em 1922).

STEIN, Edith. L'empatia di Edith Stein. Trad. Michele Nicoletti. Milano, Italia: Franco Angeli, 1992. (Original publicado em 1917). 